\title{
TFRS 15 Müşteri Sözleşmelerinden Hasılat Standardının Otel İşletmeleri Açısından Değerlendirilmesi

\author{
(Evaluation of IFRS 15 Revenue Standard From Contracts with Customers in Terms of \\ Hotel Operations)
}

\author{
Hande UYAR OĞUZ iD a Seyit Ahmet SOLMAZ iD b Burcu ERGÜN iD c \\ a Bartın Üniversitesi, İktisadi ve İdari Bilimler Fakültesi Turizm İşletmeciliği Bölümü, Bartın, Türkiye. handeuyar@bartin.edu.tr \\ b Harran Üniversitesi, Turizm ve Otel İşletmeciliği Yüksekokulu, Şanlıurfa, Türkiye. seyitahmetsolmaz@harran.edu.tr \\ c Bartın Üniversitesi, Sosyal Bilimler Enstitüsü, İşletme Anabilim Dalı, Bartın, Türkiye. burcuergun10@gmail.com
}

\begin{tabular}{|c|c|}
\hline MAKALE BİLGİSİ & ÖZET \\
\hline Anahtar Kelimeler: & Amaç - Bu çalışma ile otel işletmelerinin hasılat kalemleri, Türkiye Finansal Raporlama Standartları TFRS \\
\hline $\begin{array}{l}\text { TFRS } 15 \\
\text { Hasılat Standardı } \\
\text { Otel İşletmeleri }\end{array}$ & $\begin{array}{l}15 \text { Müşteri Sözleşmelerinden Hasılat boyutuyla ele alınmıştır. Hasılat, kar elde etme amacı ile kurulmuş her } \\
\text { işletme gibi otel işletmeleri için de performansın değerlendirilmesinde önemli bir unsurdur. TRFS } 15 \\
\text { Müşteri Sözleşmelerinden hasılat kavramı beş aşamalı bir edim süreci gerektirmektedir. Çalışmada, her bir } \\
\text { edim sürecinin muhasebe kayıtlarına aktarımı TFRS } 15 \text { ilkeleri doğrultusunda gerçekleştirilmiştir. }\end{array}$ \\
\hline $\begin{array}{l}\text { Gönderilme Tarihi } 16 \\
\text { Ekim } 2019\end{array}$ & $\begin{array}{l}\text { Yöntem - Çalışmada otel işletmelerinin gelir kalemleri oda, yiyecek-içecek ve diğer gelirler olmak üzere üç } \\
\text { kategoride sınıflandırılmıştır. Bu sınıflandırmalar doğrultusunda bir otel işletmesinin en fazla gelir elde } \\
\text { ettiği kalemler olan oda ve yiyecek-içecek gelirleri TFRS } 15 \text { Müşterilerle Yapılan Sözleşmelerden Doğan }\end{array}$ \\
\hline $\begin{array}{l}\text { Revizyon Tarihi } 21 \text { Mart } \\
2020\end{array}$ & $\begin{array}{l}\text { Hasılat Standardına uygun olarak örnek olaylarla muhasebeleştirilmiştir. Çalışmada ayrıca TFRS } 15 \text { dikkate } \\
\text { alınmadan yapılan muhasebe kayıtlarına da yer verilerek her iki kaydın karşılaşırması yapılmıştır. }\end{array}$ \\
\hline $\begin{array}{l}\text { Kabul Tarihi } 25 \text { Mart } \\
2020\end{array}$ & $\begin{array}{l}\text { Bulgular - Çalışmada otel işletmelerinin gelir kalemleri oda, yiyecek-içecek ve diğer gelirler olmak üzere üç̧ } \\
\text { kategoride sınıflandırılmıştır. Bu sınıflandırmalar doğrultusunda bir otel işletmesinin en fazla gelir elde } \\
\text { ettiği kalemler olan oda ve yiyecek-içecek gelirleri TFRS } 15 \text { Müşterilerle Yapılan Sözleşmelerden Doğan } \\
\text { Hasılat Standardına uygun olarak örnek olaylarla muhasebeleştirilmiştir. Çalışmada ayrıa TFRS } 15 \text { dikkate } \\
\text { alınmadan yapılan muhasebe kayıtlarına da yer verilerek her iki kaydın karşıştırması yapılmıştır. }\end{array}$ \\
\hline $\begin{array}{l}\text { Makale Kategorisi: } \\
\text { Araştırma Makalesi }\end{array}$ & $\begin{array}{l}\text { Tartışma - Otel işletmelerinde gelir kayıtlarının beş edim yükümlülüğ̈ çerçevesinde ve TFRS } 15 \text { ilkeleri } \\
\text { doğrultusunda tutulmuyor olması, elde edilmeyen gelirlerin işletme kayıtlarına yansımasına, bunun da } \\
\text { işletme paydaşları başta olmak üzere finans çevrelerine yanlış bilgi aktarımına sebebiyet vereceği } \\
\text { görülmektedir. }\end{array}$ \\
\hline
\end{tabular}

\begin{tabular}{|c|c|}
\hline ARTICLE INFO & ABSTRACT \\
\hline $\begin{array}{l}\text { IFRS } 15 \\
\text { Revenue Standard } \\
\text { Hotel Operations }\end{array}$ & $\begin{array}{l}\text { Purpose - With this study, the revenue items of hotel enterprises are discussed with Turkey Financial } \\
\text { Reporting Standards IFRS } 15 \text {.Because, Revenue is one of the factors in evaluating the performance of the } \\
\text { company as well as the hotel companies. TRFS 15, The Concept of Revenue from Customer Contracts } \\
\text { requires a five-stage performance process. In this study, the transfer of each performance process to the } \\
\text { accounting records has been realized in accordance with the principles of TFRS } 15 . \mathrm{M}\end{array}$ \\
\hline $\begin{array}{l}\text { Received } 16 \text { October } \\
2019 \\
\text { Revised } 21 \text { March } 2020 \\
\text { Accepted } 25 \text { March } 2020\end{array}$ & $\begin{array}{l}\text { Design/methodology/approach - In this study, income items of hotel establishments are classified into } \\
\text { three categories as room, food and beverage and other income. According to these classifications room and } \\
\text { food and beverage revenues, which are the items with the highest income from a hotel business, are } \\
\text { accounted with examples for in accordance with TFRS } 15 \text { Revenue from Contracts with Customers. The } \\
\text { study also contains accounting records made without taking into account TFRS } 15 \text { and the accounts also } \\
\text { both records are compared. }\end{array}$ \\
\hline \multirow[t]{2}{*}{$\begin{array}{l}\text { Article Classification: } \\
\text { Research Article }\end{array}$} & $\begin{array}{l}\text { Findings - The current TFRS } 15 \text { Revenue standards from the Customer Agreements are used for the correct } \\
\text { transfer of the income obtained from the ordinary operations of the hotel businesses to the financial } \\
\text { statements needs to be considered. Accounting records must be followed before arrival, after the stay and } \\
\text { after departure of the guest/guests and the transfer of income to the financial statements should only be } \\
\text { realized after the performance of the goods and services especially after the guest / guests have left the } \\
\text { hotel. }\end{array}$ \\
\hline & $\begin{array}{l}\text { Discussion - It is seen that income records are not kept in line with TFRS } 15 \text { principles within the scopeof } \\
\text { five performance obligations in hotel businesses, reflecting the unearned income to the business records and } \\
\text { this may cause false information transfer to financial circles,especially to business stakeholders. }\end{array}$ \\
\hline
\end{tabular}




\section{GİRIŞ}

Uluslararası Menkul Kıymetler Komisyonları Örgütü Teknik Komitesi tarafından 1989 yılında hazırlanan "Uluslararası Halka Arzlar" adlı raporda mali raporlama yükümlülüklerinin uluslararası menkul kıymet ihracatında en fazla problem yaşanan konulardan biri olduğu ifade edilmiştir. Hisse senetleri hem İstanbul Menkul Kıymetler Borsası, hem de New York Borsasında kote edilmiş olan Turkcell, 2000 yılı ilk 9 ayı içerisinde iki farklı faaliyet sonucu açıklamıştır. Buna göre Türkiye'de ilk 9 ayda 23,7 trilyon TL zarar açıklayan Turkcell, New York Borsası'nda 157,8 trilyon TL kâr açıklamıştır. Bu iki farklı durumun ortaya çıkması bize Amerikan Genel Kabul Görmüş Muhasebe Standartları ile Türk Sermaye Piyasası Kurulu muhasebe standartlarının farklı olduğunu göstermektedir. (Milliyet Gazetesi, 09 Kasım 2000)

Konu ile ilgili verilebilecek bir başka örnek de Almanya'nın meşhur markası BMW otomobillerine ilişkindir. Avrupa'nın birçok büyük şirketi gibi BMW' de finansal tablolarının Amerikan muhasebe standartlarına göre hazırlanması reddederek, Almanya muhasebe standartlarına uygun olarak hazırlamıştır. Bu durum ise BMW gibi dünyanın en karlı şirketlerinden birinin hisse senetlerinin Amerikan borsalarında işlem görememesine neden olmuştur (İbiş ve Akarçay, 2003: 252). Görüldüğü üzere finansal raporlamadaki standardizasyon eksikliği özellikle uluslararası ölçekte faaliyet gösteren işletmeler için büyük bir sorun teşkil etmektedir.

Ülkeler, Nasdaq gibi borsalarda şirket hisse senetlerinin işlem görmesini sağlamak ve farklı muhasebe uygulamalarının ortaya koyduğu problemleri gidermek amacı ile muhasebede standartlaşma çabası içerisine girmişlerdir (Korkmaz vd., 2007: 97). Bununla birlikte çok uluslu veya uluslararası işletmeler yatırım yapmayı planladıkları ülkelerdeki muhasebe işlemlerinin anlaşılır olması ve bu işlemlerin kolayca adapte edilebilir olmasını beklemektedirler (Bekçi, 2007: 28). Finansal tabloların anlaşılır, net ve en önemlisi karşılaştırılabilir olmasını sağlamak amacı ile tüm dünyada ortak, uluslararası muhasebe standartları oluşturulmuştur. Bu bağlamda 1973 yılında Amerika Birleşik Devletleri, İngiltere, Almanya, Japonya, Fransa, Kanada, Meksika ve Hollanda'nın içerisinde bulunduğu Uluslararası Muhasebe Standartları Komitesi (IASC) kurulmuştur (Hatipoğlu,2009: 12). Bu komite, kamuya açıklanan denetlenmiş mali tablolarda uygulanması gereken muhasebe standartlarını belirlemek ve bu standartların dünya çapında benimsenmelerini sağlamak amacıyla kurulmuştur. (Bostanc1, 2002: 73; İbiş ve Özkan, 2006: 28).

Dünyadaki muhasebe uygulamaları incelendiğinde kabul görmüş iki muhasebe standart seti olduğu görülmektedir. Bunlardan ilki Uluslararası Muhasebe Standartları Kurulu tarafından oluşturulan Uluslararası Finansal Raporlama Standartları-UFRS, diğeri ise ABD'de Finansal Muhasebe Standartları Kurulu tarafından oluşturulan ABD Muhasebe İlkeleri'dir. Bu iki muhasebe standart seti arasındaki temel fark ise, IASB'nin “ilke Bazlı” standartlar olmasına karşın; US GAAP standartlarının “Kural Bazlı" olmasidır.

Bugün, 100'den fazla ülke IASB (Uluslararası Finansal Standart Komitesi) tarafından yayımlanan tek tip uluslararası muhasebe standartlarını benimsemiştir (Karadağ, 2010: 3). Avrupa Bakanlar Konseyi, tüm AB bölge şirketlerinin 1 Ocak 2005 veya sonrasında başlayan hesap dönemleri için UFRS kullanarak rapor vermelerini zorunlu kılan düzenlemeyi onaylamıştır (Karadağ, 2010: 3). Bu bağlamda turizm şirketleri de Uluslararası Finansal Raporlama Standartlarını benimsemek durumunda kalmışlardır. Feng ve arkadaşlarının 2017 yılında yaptıkları çalışma ile 18 farklı ülkede faaliyet gösteren turizm işletmelerinin UFRS'ye zorunlu geçiş yaptıkları görülmektedir. UFRS'yi uygulayan turizm firmaları tablo 1'de gösterilmiştir.

Bu tabloya göre Avrupa'da bulunan ülkelerin tamamını 2005 yılında gönüllü olarak UFRS'yi kabul ettikleri, bununla birlikte en yüksek geçiş oranı sağlayan ülkelerin sırasıyla \%76,92 ile Danimarka, \%74,07 ile İtalya ve \%72,00 oranı ile İsviçre olduğu görülmektedir. En düşük oranla geçişi ise \%40 oranında Brezilya' daki turizm işletmelerinin sağladıkları gözlenmiştir. 
H. Uyar Oğuz - S. A. Solmaz - B. Ergün 12/2 (2020) 1489-1504

Tablo 1: UFRS'ye Zorunlu Geçiş Yapan Turizm Firmalarının Geçiş Yılları

\begin{tabular}{|r|c|c|c|c|c|}
\hline \multicolumn{1}{|c|}{ ÜLKE } & $\begin{array}{c}\text { UFRS'ye } \\
\text { Geçiş y1li }\end{array}$ & UFRS öncesi Sayı & UFRS sonrası Say1 & $\begin{array}{c}\text { UFRS öncesi } \\
\text { Oran (\%) }\end{array}$ & $\begin{array}{c}\text { UFRS sonrası } \\
\text { Oran (\%) }\end{array}$ \\
\hline Avustralya & 2005 & 13 & 20 & 39.39 & 60.61 \\
\hline Avusturya & 2005 & 4 & 3 & 57.14 & 42.86 \\
\hline Brezilya & 2010 & 3 & 2 & 60.00 & 40.00 \\
\hline Danimarka & 2005 & 6 & 20 & 23.08 & 76.92 \\
\hline Finlandiya & 2005 & 3 & 5 & 37.50 & 62.50 \\
\hline Fransa & 2005 & 28 & 32 & 46.67 & 53.33 \\
\hline Almanya & 2005 & 9 & 22 & 29.03 & 70.97 \\
\hline Hong Kong & 2005 & 29 & 57 & 33.72 & 66.28 \\
\hline Hindistan & 2011 & 4 & 2 & 66.67 & 33.33 \\
\hline Italya & 2005 & 7 & 20 & 25.93 & 74.07 \\
\hline Hollanda & 2005 & 3 & 7 & 30.00 & 70.00 \\
\hline Yeni Zellanda & 2007 & 21 & 19 & 52.50 & 47.50 \\
\hline Portekiz & 2005 & 3 & 5 & 37.50 & 62.50 \\
\hline Güney Afrika & 2005 & 2 & 2 & 50.00 & 50.00 \\
\hline Ispanya & 2005 & 14 & 23 & 37.84 & 62.16 \\
\hline İsveç & 2005 & 3 & 5 & 37.50 & 62.50 \\
\hline İsviçre & 2005 & 7 & 18 & 28.00 & 72.00 \\
\hline Birleşik Krallı & 2005 & 49 & 89 & 35.51 & 64.49 \\
\hline Toplam & & 208 & 351 & 37.21 & 62.79 \\
\hline
\end{tabular}

Kaynak: Feng ve diğ.(2017). Does IFRS Adoption Decrease The Cost Of Equity Of The Global Tourism Firms? Tourism Economics, p.7

Her ne kadar ülkeler UFRS'yi kabul etmek zorunda kalmış olsalar da bu geçişin kendilerine sağlayacağı birçok yarar bulunmaktadır. Bu yararlar arasında şeffaflığın geliştirilmesi, sermaye maliyetlerinin azalması, daha etkin kaynak tahsis kararları, yatırımcılar için dünya çapında karşılaştırabilme olanağının artması, sermaye hareketinin arttırılması ve daha etkin sermaye tahsisi, birçok muhasebe fonksiyonunun merkezileşmesi ve finans çalışanlarının ek bir eğitime ihtiyaç duymaksızın başka ülkeye transferini kolaylaştırması sayılabilir (Karadağ 2010: 3).

Deloitte (2008) tarafından hazırlanan çalışmada ise Uluslararası Finansal Raporlama Standartlarının (UFRS) yararları aşağıdaki gibi sıralanmıştır:

- Mevcut uygulamalara yeni bir görünüm sağlaması,

- Dönüşüm, düzene koyma ve birleştirme için bir katalizör olması,

- İlkelere dayalı bir uygulama için fırsat sunması,

- Küresel pazarın kapılarının açılmasına yardımcı olması.

Deloitte (2008) UFRS'ye geçişin iki şekilde gerçekleşebileceğini ifade etmiştir. Bunlardan ilki ve Avrupa Birliğine üye olan devletlerce hızlı bir şekilde geçişe zorlanılan "Hepsi Bir Arada Yaklaşımı" ile "Kademeli Geçiş" Yaklaşımıdır. Birinci yaklaşımda Avrupa'daki kanun koyucular şirketleri zaman çizelgeleri yardımıyla UFRS sistemini bir an önce benimsemeye zorlamışlardır. Kademeli yaklaşımı benimseyenler ise UFRS sistemine yıllar bazında ve daha sistematik bir şekilde geçişi gerçekleştirmeyi uygun görmüşlerdir.

$\mathrm{Bu}$ çalışma, hem ürün hem de hizmet üretimini aynı çatı altında gerçekleştiren otel işletmelerinde elde edilen gelirlerin mali tablolara yansitılmadan önce Türkiye Finansal Raporlama Standardı (TFRS), Müşteri Sözleşmelerinden Doğan Hasılat (TFRS 15) Standardı doğrultusunda muhasebe kayıtlarına nasıl işlenmesi gerektiği ile ilgili uygulamalı öneriler getirmektedir. $\mathrm{Bu}$ kayıtların otel işletmelerinin Müşteri Sözleşmelerinden Doğan Hasılat (TFRS 15) Standardına uygun olarak gerçekleştiriliyor olması, özellikle uluslararası otel işletmeleri açısından daha fazla önem arz etmektedir. Öyle ki hasılatın mali tablolara ev sahibi ülke mi yoksa faaliyetlerine devam ettiği ülke standartlarıyla mı yansitılacağı önemli bir sorundur. 
Türkiye'deki otel işletmelerinin gelirlerinin muhasebeleştirilmesi işlemini TFRS 15 standartlarını dikkate almadan yapıyor olmaları hasılatın finansal tablolara yanlış yansıtılması sonucunu doğurabilir ki bu durum işletmelerin gelecek dönem plan ve kararlarını, işletmenin kamu kurum ve kuruluşları ile olan ilişkilerini, kredi kurumlarının kararlarını olumsuz yönde etkileyebilecektir.

Çalışmada öncelikle otel işletmelerinin elde ettikleri gelir kalemleri belirlenmiştir. Akabinde bu gelirlerin TFRS 15 dikkate alınmadan yapılan muhasebe kayıtları ile TFRS 15'e uygun olarak gerçekleştirilmesi gereken muhasebe kayıtları örneklerle açılanmıştır.

\section{TFRS 15 (Türkiye Finansal Raporlama Standardı Müşteri Sözleşmelerinde Hasılat 15)}

Bilindiği üzere 2011 tarih ve 660 sayılı Kanun Hükmünde Kararname ile Kamu Gözetimi Muhasebe ve Denetim Standartları Kurumu kurulmuş ve bu kuruma Türkiye Muhasebe Standartlarının (TMS/TFRS) oluşturulabilmesi için yetki verilmiştir (Sağlar ve Yüce,2015: 47). Bu düzenlemeler ile birlikte şirketler TFRS'ye uygunluk temeli üzerinde yeni finansal tablolar düzenlemeye başlamışlardır. Kamu Gözetim ve Denetim Standartları Kurumu tarafından muhasebe standartları ise (KGK,2019;

> Büyük ve Orta Boy İşletmeler için Finansal Raporlama Standardı (BOBİ FRS),

> Küçük ve Mikro İşletmeler için Finansal Raporlama Standardı Taslak Metni (KÜMİ FRS),

> Türkiye Muhasebe Standartları /Türkiye Finansal Raporlama Standartları (TMS/TFRS) şeklinde sıralanmıştır.

Aşağıdaki tablo Türk Ticaret Kanunu'na uygun olarak Türkiye Muhasebe Standartlarını uygulamak zorunda olan firmaları göstermektedir. Bu bağlamda büyük şirketlerin yanı sıra küçük ve orta ölçekli işletmelere de karşılaştırılabilirlik ve şeffaflık ihtiyaçları doğrultusunda 29 Temmuz 2017 yılından itibaren Finansal Raporlama Standardı getirilmiş ve Resmi Gazete yayınlanmıştır ( Kılıç,2017:11).

Tablo 2: Türkiye Muhasebe Standartları

\begin{tabular}{|c|c|c|c|c|}
\hline & $\begin{array}{l}\text { Türkiye Muhasebe } \\
\text { Standartları }\end{array}$ & & & \\
\hline \multirow{4}{*}{$\begin{array}{c}\text { BAĞIMSIZ DENETIME } \\
\text { TABİI } \\
\text { OLANLAR }\end{array}$} & TMS/TFRS TAM SET & \multicolumn{3}{|l|}{ KAYİK İşletmeleri } \\
\hline & \multirow[t]{2}{*}{ BOBİ-FRS } & \multirow[t]{2}{*}{$\begin{array}{l}\text { KAYİK'ler } \\
\text { Dışındaki } \\
\text { İşletmeler }\end{array}$} & $\begin{array}{l}\text { Büyük } \\
\text { İşletmeler }\end{array}$ & Ölçekli \\
\hline & & & $\begin{array}{l}\text { Küçük } \\
\text { İşletmeler }\end{array}$ & Ölçekli \\
\hline & FFMS & $\begin{array}{l}\text { Katılım Bankalar } \\
\text { Kuruluşları }\end{array}$ & ve Faizsiz & Finans \\
\hline $\begin{array}{l}\text { BAĞIMSIZ DENETIMME } \\
\text { TABİI OLMAYANLAR }\end{array}$ & KÜMİ-FRS & $\begin{array}{l}\text { Küçük ve Mikro Ö } \\
\text { (Bilanço Esasına } \\
\text { İşletmeler) }\end{array}$ & $\begin{array}{l}\text { çekli İşletmeler } \\
\text { Göre Defter }\end{array}$ & Tutan \\
\hline
\end{tabular}

Kaynak: Sağlar, J.ve Ever, D.,(2019), Büyük ve Orta Büyüklükteki İşletmeler İçin Getirilen Finansal Raporlama Standartlarının Etkileri, Osmaniye Korkut Ata Üniversitesi,Journal of Economics and Administrative Sciences, Vol: 3, Issue:2,December,2019),pp.299-310.

Kamu Gözetimi Muhasebe ve Denetim Standartları Kurumu tarafından Türkiye Finansal Raporlama Standartları; "TFRS 1 Türkiye Finansal Raporlama Standartlarmmn İlk Uygulamasl, TFRS 2 Hisse Bazl Ödemeler, TFRS 3 İşletme Birleşmeleri, TFRS 4 Sigorta Sözleşmeleri, TFRS 5 Satış Amaçlı Elde Tutulan Duran Varliklar ve Durdurulan Faaliyetler, TFRS 6 maden Kaynaklarının Araştırılması ve Değerlendirilmesi, TFRS 7 Finansal Araçlar: Açıklamalar, TFRS 8 Faaliyet Bölümleri, TFRS 9 Finansal Araçlar, TFRA 10 Konsolide Finansal Tablolar, TFRS 11 
Müşterek Anlaşmalar, TFRS 12 Diğer İşletmelerdeki Paylara İlişkin Açılamalar, TFRS 13 Gerçeğe Uygun Değer Ölçümü, TFRS 14 Düzenlemeye Dayalı Erteleme Hesapları ve TFRS 15 Müşteri Sözleşmelerinden Hasılat "şeklinde belirlenmiştir.

TFRS 15 Müşterilerle Yapılan Sözleşmelerden Doğan Hasılat Standardı 2017 yılında başlayan hesap dönemlerini kapsayan bir raporlama standardıdır. Bu standart müşterilerle yapılan sözleşmeden elde edilen gelirin muhasebe kayıtlarına nasıl aktarılacağı ile ilgili ilkeleri düzenleyen bir standarttır (www.kgk.gov.tr). Bu bağlamda standart, bir işletmenin mal ve hizmet satışı sonunda elde edeceği hasılatın finansal tablolara yansıtılması işlemlerini içerir. Burada hasılat, iş ilişkisi dolayısıyla yapılan her bir sözleşmenin muhasebeleştirilmesi esasına dayanmaktadır (www.kgk.gov.tr). İşletme bu standardı kira sözleşmeleri, sigorta sözleşmeleri, TFRS 9 Finansal Araçlar, TFRS 10 Konsolide Finansal Tablolar, TFRS 11 Müşterek Anlaşmalar, TMS 27 Bireysel Finansal Tablolar ve TMS 28 İştiraklerdeki ve İş Ortaklarındaki Yatırımlar haricindeki tüm sözleşmeler ile aynı iş kolunda faaliyetlerini devam ettiren işletmeler arasında parasal olmayan değişimler hariç uygulayabilmektedir (www.kgk.gov.tr). İşletmenin müşteriye karşı olan edim yükümlülüğü yerine getirildiği takdirde (veya getirdikçe) elde ettiği kazancı finansal tablolarına yansıtabilecektir.

Standart, 5 edim yükümlügünün yerine getirilmesini ele alan bir model öngörmektedir:

Tablo 3: TFRS 15 Beş Adımlı Model

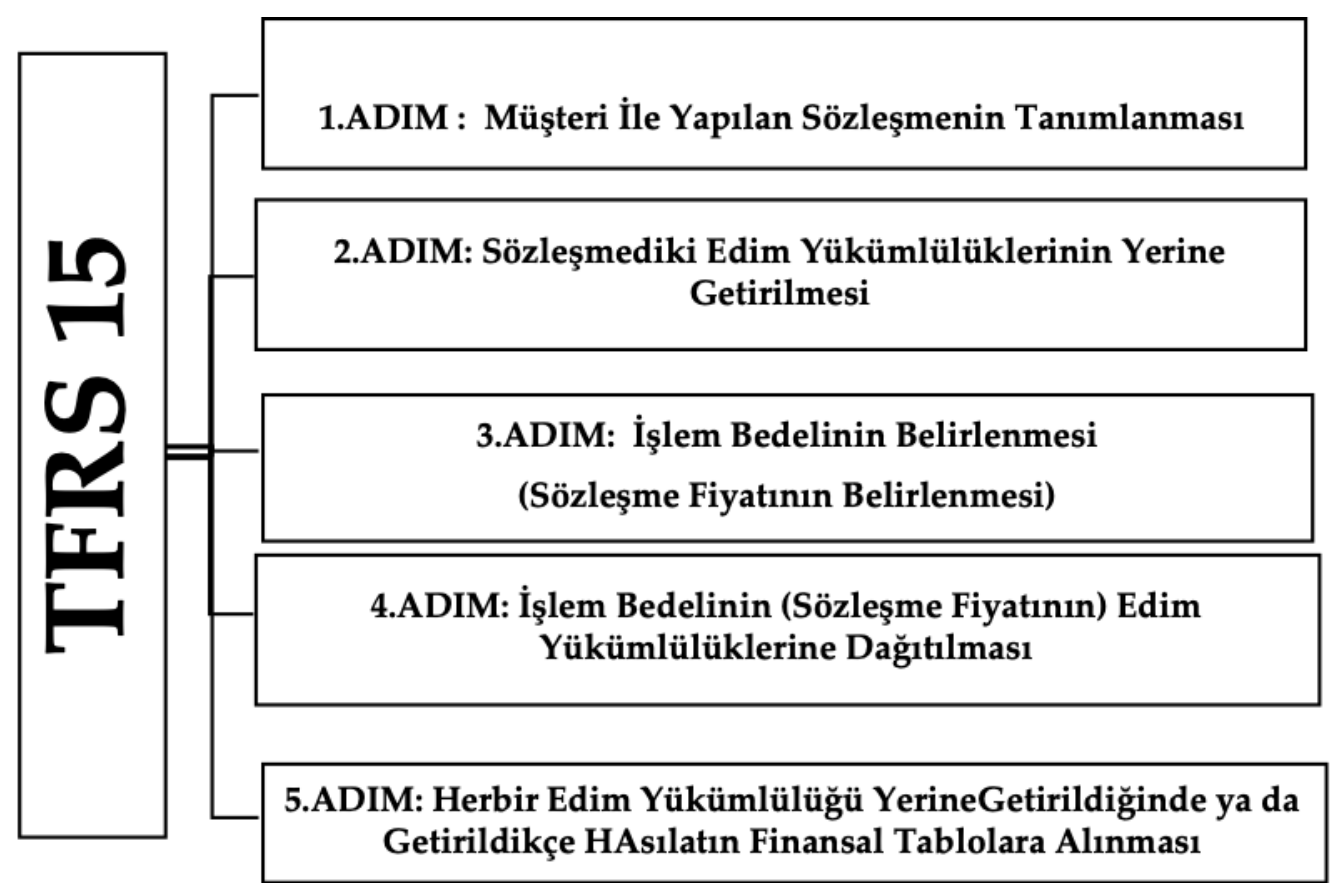

Müşteri Sözleşmelerinden Hasılatta;

$\checkmark$ Sözleşme tarafları belirlenir,

$\checkmark$ Her iki taraf sözleşmenin yerine getirileceğini taahhüt eder,

$\checkmark$ Devredilecek mal hizmetlerin hakları ve ödeme koşulları tanımlanı,

$\checkmark$ Hak kazanılacak bedelin tahsisi muhtemel ve sözleşme ticari ise bu standart kapsamında muhasebeleştirilmektedir ( Ataman ve Cavlak, 2017: 408).

Sözleşme belirlendikten sonra ise müşterilere sunulacak mal ve hizmet edim yükümlülüklerinin belirlenmesi gerekmektedir. Burada önemli olan husus her edim yükümlülüğünün ayrı ayrı muhasebeleştirilmesi gerekliliğidir (Olsen ve Weirich,2010:57). Edim yükümlülükleri (TFRS 15/22);

$\checkmark$ Bir mal veya hizmet serisinden -ki müşteriye benzer veya aynı şekilde devredilecek - ,

$\checkmark$ Farklı mal ve hizmetler paketinden oluşabilmektedir.

Edim yükümlülügünün üçüncü aşaması sözleşme fiyatının belirlenmesi aşamasıdır. Bu aşamada işletme her bir sözleşme için bir fiyat belirlemektedir. Diğer bir ifade ile işlem bedeli işletme tarafından müşteriye taahhüt edilen mal ve hizmetler karşılığında elde etmeyi beklediği parasal tutardır (Kılıç, 2017: 24). 
Standart kapsamında işlem fiyatı belirlenirken aşağıdaki faktörler birlikte değerlendirilmelidir (UFRS 15, madde 48, 8);

$\checkmark$ Değişken Bedel,

$\checkmark$ Değişken Bedeli Sabitleyen Tahminler,

$\checkmark$ Sözleşmede Önemli Bir Finansal Unsurun Varlığı,

$\checkmark$ Nakdi Olmayan Bedel,

$\checkmark$ Müşteriye Ödenebilir Bedel.

İşlem bedelinin bir diğer deyişle sözleşme fiyatının gerçekleşen her edim yükümlülüğü sonucunda dağıtılması gerekmektedir. İşlem bedeli edim yükümlülüklerine aşağıdaki yöntemler aracılığıyla dağıtılır ( EY,2016:160):

$\checkmark$ Tek Başına Satış Fiyatı Belirleme,

$\checkmark$ İlişkili Tek Balına Satış Fiyatı Yöntemi,

$\checkmark$ Değişken Maliyetin Dağıtılması,

$\checkmark$ İndirimlerin Dağıtılması,

$\checkmark$ Sözleşme Başlangıcından Sonraki Fiyat Değişimleri,

$\checkmark$ UFRS 15 Kapsamı Dışındaki Sözleşme Fiyatının Dağıtılması.

Edim yükümlülüğünde belirtilen mal hizmetlerin müşteriye devri ile birlikte hasılat tablolara alınacaktır. Edim yükümlülüğünün yerine getirilmesine ilişkin iki yaklaşım karşımıza çıkmaktadır. Bunlardan ilki edim yükümlüğünün Belirli Bir Anda Yerine Getirilmesi Yaklaşımı ve diğer ise Edim Yükümlülügüunün Zamana Yayılı olarak yerine getirilmesi yaklaşımıdır.

Bir edim yükümlülüğünün zaman yayılı olarak olabilmesi için şu şartlardan birini karşıllyor olması gerekmektedir (KGK,2017b:46):

> İşletme edimi yerine getirdikçe, müşterinin edimin sağladığı faydayı aynı anda alıp tüketmesi (Örneğin; bakım, temzilik hizmetleri),

> İşletme ediminin, oluşturuldukça veya geliştirildikçe (örneğin, yapım aşamasındaki işler)

kontrolü müşteriye geçen bir varlık oluşturması veya geliştirmesi veya

> İşletme ediminin, işletme için alternatif kullanımı olan bir varlık oluşturmaması ve işletmenin

o güne kadar tamamlanan edime karşılık yapılacak ödeme üzerinde hukuken icra edilebilir

bir tahsil hakkının bulunması.

İşletme, o güne kadar tamamlanan edimine karşıllk kendisine yapılacak ödeme üzerinde yasal bir tahsil hakkının olup olmadığıı değerlendirirken, sözleşmeyi ilgilendiren kanunlarla birlikte sözleşme şartlarını da göz önünde bulundurur. Sözleşmenin, işletmenin taahhüt etmiş olduğu biçimde edimini yerine getirememesi dışındaki nedenlerle müşteri veya başka bir tarafça feshedilmesi durumunda, işletme sözleşme süresince her zaman en az o güne kadar tamamladı̆̆ı edimi karşılayan bir tutara hak kazanmalıdır (Saban ve diğerleri,2019:45).

Otel işletmeleri hizmet sektöründe faaliyetlerine devam eden işletmeler olması dolayısıyla bu işletmelerde edim yükümlülüklerinin yerine getirilmesinde zaman yayılı yaklaşım benimsenmelidir.

\section{Otel İşletmeleri ve Otel İşletmelerinde Hasılat Kavramı}

İşletme paydaşları için elde edilen kazanç, başarı ya da başarısızlığın ölçümünde veya başarının hedeflenen düzeyde olup olmadığının belirlenmesinde en önemli göstergelerden biri olarak karşılarına çıkmaktadır. Hasılatın finansal tablolara aktarımının nasıl gerçekleşeceği ile ilgili mevzuat gerek uluslararası finansal raporlama standardında gerekse vergi mevzuatında düzenlenmiştir (Ataman ve Cavlak, 404: 2017).

TFRS 15' e göre gelir; Ortakların yaptığı katkılarla ilgili olanlar hariç olmak üzere, hesap dönemi boyunca öz kaynakta bir artışa yol açan varlık girişleri veya varlıklarda artışlar veya yükümlülüklerde azalmalar şeklinde tanımlanmıştır.

Kamu Gözetim Kurumu (KGK) geliri; "muhasebe döneminde, ekonomik yararlarda işletme bünyesine varlı girişi veya diğer şekillerdeki varlık çoğalmaları sonucundaki artışı veya öz kaynaklarda hissedarların yatırdıkları fonlar dışındaki kalemlerde artış meydana getiren borçlardaki azalma" olarak ifade etmektedir. Gelir, işletme eylemleri sonucu çeşitli varlıklarda artış meydana getirir. Bu varlıklara nakitler, alacaklar, verilen mal ve hizmet 
karşılığı alınan mal ve hizmetler örnek verilebilir. Gelir, borçlu bir işletmenin alacaklısına mevcut borcu karşılığı mal ve hizmet sunması şeklinde de gerçekleşebilmektedir. Türkiye Muhasebe Standartları (TMS) 18' e göre gelir, finansal tablolarm hazırlanma ve sunulma esaslarına ilişkin kavramsal çerçevede, hesap dönemi boyunca, sermayedarların katkılarıyla ilgili olanlar dışındaki nakit girişleri veya varlıklardaki artışlar veya borçlardaki azalışlar olarak öz kaynaklarda artışa neden olan ekonomik faydalardaki artışlar olarak tanımlanmıştır. Burada görülmektedir ki gelir, hem hasılatı hem de kazancı içeren bir kavramdır. TMS 18 hasılatı; sermaye katkısı dışında, işletmenin faaliyetleri ile oluşan ve öz kaynakta artışla sonuçlanan fayda olarak tanımlamıştır. Cemalciler ve Önce (1999: 634) ise hasılatı; işletmenin ürettiği mal ve hizmet ediminin yerine getirilmesi amacı ile gerçekleştirilen ana ve yan faaliyetler sonucu bir dönem içerisinde varlıklarda meydana gelen artış olarak tanımlamışlardır.

Yukarıdaki tanımlardan hareketle hasılatın üç önemli özelliği olduğu söylenebilir. Bunlar;

$>$ Kazanma sürecinin bir sonucu olması,

> Bir işletmenin mal, hizmet veya mal ve hizmet üretimi sonucu elde edilen nakit girişleri ile sonuçlanması ve

> Raporlanan girişlerde brüt tutarın esas alınmasıdır.

Duman (2007) hasılat kavramında sözleşmede belirtilen tutar karşıllı̆̆ üretilen mal ve hizmetlerin teslim edilmesi gerektiğini ifade etmiştir. Böylelikle borçlarda azalma meydana gelecektir. Bu işlemde üçüncü kişilerden tahsil edilen tutarların işletme tarafından ekonomik bir yarar olmadığını da ifade etmiştir. Bu bağlamda otel işletmelerinde gelire konu olan asıl iki temel unsur bulunmaktadır. Bunlar;

$>$ Oda gelirleri ve

> Yiyecek-içecek gelirleridir.

> Diğer gelirler, otel işletmelerinde gelir getiren bölümler tarafından elde edilen gelirlerdir.

Genel anlamda konaklama işletmelerinin faaliyet süreleri boyunca birçok mali nitelikli işlem yaptıkları görülmektedir. Bu işlemlerin bazıları varlık ve yabancı kaynaklar üzerinde etki yaratırken, bazıları öz kaynaklar üzerinde etki yaratmaktadır. Öz kaynaklar üzerinde etki yaratan mali nitelikli işlemlerin büyük bir kısmı gelir tablosu hesaplarında izlenmektedir. Bazı mali işlemler dönem içinde maliyet hesaplarında izlenir ve dönem sonunda gelir tablosu hesaplarına aktarılır (Şengel, 2017: 104)

Otel işletmelerinin her türlü hizmet satışında elde ettiği gelir için KDV hesaplanır ve bu kayıtlar 391 Hesaplanan KDV hesabında izlenir. KDV'nin hesaplanması ve kaydedilmesi işlemleri yurt içi mal ve hizmet satın alımları ile yurt dışı mal ve hizmet satın alımları arasında da farklılık göstermektedir. Yurt içi mal ve hizmet satışlarında hesaplanan KDV faturada gösterilirken, yurt dışı mal ve hizmet satın alımları için KDV'nin müşteriler adına düzenlenen faturada gösterilmediği 26 no'lu KDV Genel Tebliğinde belirtilmiştir (Şengel, 2017: 104).

\subsection{Otel İşletmelerinde Gelirlerin Muhasebeleştirilmesi}

Otel işletmelerinde üretilen mal ve hizmetlerin satışı sonucu elde edilen gelirlerin takibi, üretim işletmelerine göre farklılıklar göstermektedir. Bu farklılıklar aşağıdaki şekilde sıralanabilir (Çetiner, 2002: 243):

> Üretim işletmelerinde talebin olmadığı ya da yoğun olduğu dönemlerde üretim stoklanabilirken, otel işletmelerinde üretilen mal ve hizmetlerin üretildiği an tüketildiği görülmektedir. Tüketimin gerçekleştiği an satışın gerçekleştiği an olduğu için bu durumun hızlıca ön büroya akışı gerekir.

> Otel işletmelerinde çok farklı mal ve hizmet satışa sunulmaktadır. Bu mal ve hizmetlerin konaklama şekline göre bir bütün olarak (her şey dâhil) veya ayrı ayrı fiyatlandırıldığı görülür.

> Satışlar TL cinsinden veya yabancı paralar cinsinden olabilmektedir.

> Üretim işletmelerinde üretilen mallar satış gelirleri ve maliyetleri olmak üzere ayrı ayrı iki ayrı kalemde izlenebilirken, otel işletmelerinde sunulan birçok hizmetin birleştirilerek tek bir satış geliri ve maliyet 
hesabında izlenmesi gerekmektedir. Örneğin üretilen yemeklerin tamamı yiyecek gelirleri hesabında izlenmektedir.

Otel işletmelerinde mal ve hizmetlerin stoklanması söz konusu olamadığından, otelin en temel gelir kaynağı olan oda satışları başta olmak üzere yiyecek-içecek satışlarından elde ettiği gelir ile ilgili kayıt işlemlerinin zamanında ve eksiksiz olarak gerçekleşmesi gerekmektedir. Öyle ki, bunun için ön büro departmanında konuklara ait folio'ların (hesap kartlarının) takibi öncelikle önem arz etmektedir.

Günümüz modern otel işletmelerinde birbiri ile entegre edilerek kullanılan otomasyon programları finansal işlemlerin takibinde büyük kolaylık sağlamaktadır. Otel işletmeleri için de çok farklı ihtiyaçlara karşılık farklı çözümler üretebilen modüller geliştirilmiştir. Aşağıdaki tablo bir otel işletmesinin genel işleyişini göstermektedir. Tabloda yer alan ön büro modülü tesiste tüm gelirlerin toplandığ1 yerdir ve burada her bir konuk için elde edilen gelirlerin takibi başta olmak üzere konuk ile ilgili her türlü işlem buradan takip edilmektedir. Örneğin konuğun gerçekleştirdiği internet, telefon, oda servisi gibi harcamaları ile konuğun her türlü ihtiyaçlarının neler olduğu ve nasıl giderildiğine dair tüm işlemler burada takip edilmektedir. POS (point of sale-satış noktası) otelin farklı noktalarında gerçekleştirilen satışların özellikle yiyecek-içecek satışlarının takibi ile konuk hesaplarına aktarılmasına destek veren bir modüldür. Stoklar ile bunların maliyet kontrolleri stok-maliyet kontrolden gerçekleştirilir. Modüllerle ilgili bilinmesi gereken en önemli konu bu modüllerin bir portal yardımıyla birbirlerine bağlantılı olmasıdır. Bu bağlamda muhasebe departmanında kullanılan muhasebe programı ile entegre çalışan modüller gelirler başta olmak üzere ödemeler, faturalar, stoklar ve stok kayıtları, maliyet hesaplamaları ve giderlerin daha hızlı takip edilmesini sağlamaktadır.

\section{Şekil 1. Otelin Genel İşleyişi}

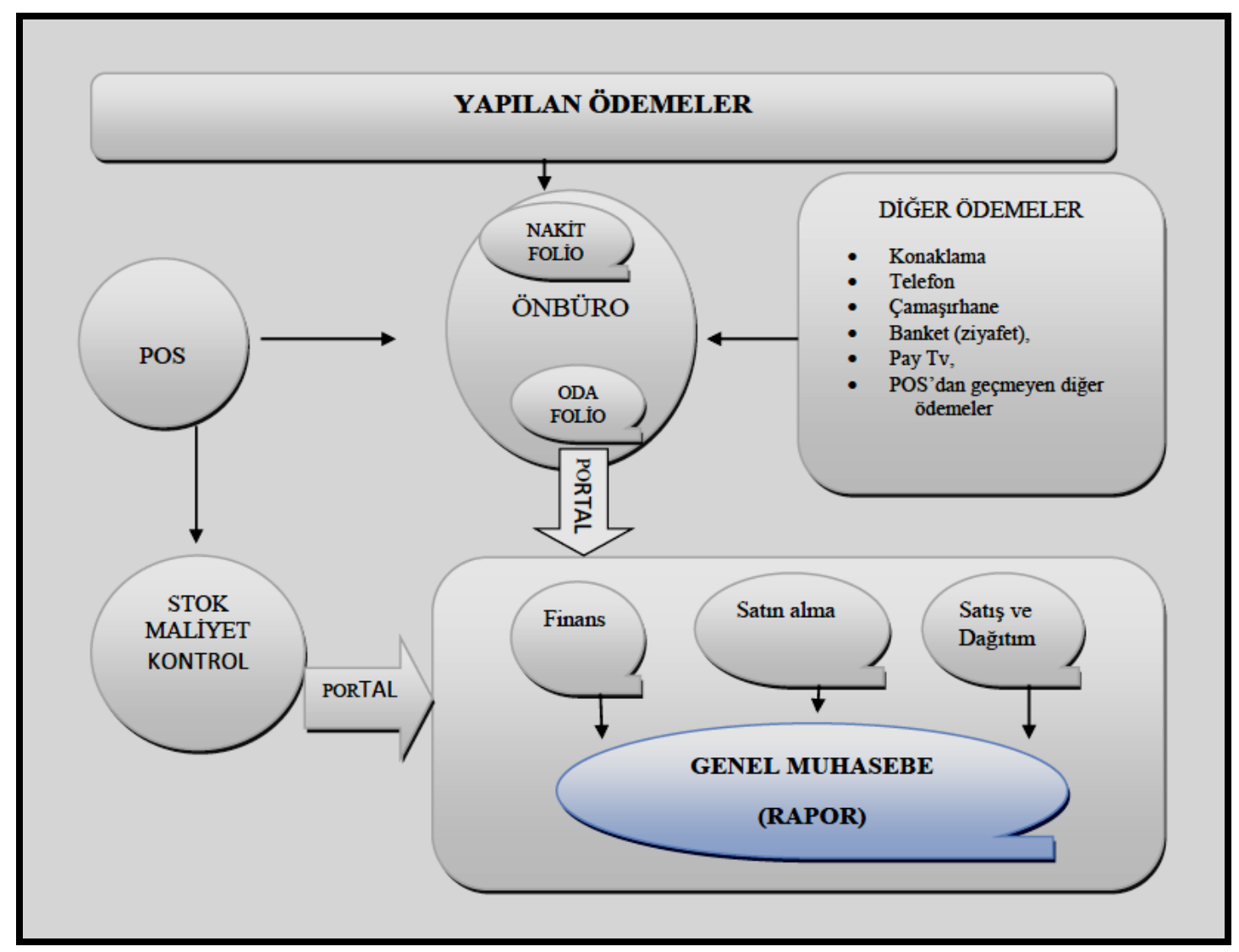

Kaynak: Milli Eğitim Bakanlığı,(2013), Ön büroda Seyahat İşlemleri, Ankara.

Bilindiği üzere otel işletmelerinde gelirler öz kaynak artışı sağlar. Bu nedenle oda gelirleri ile yiyecek-içecek gelirleri dışındaki kira gelirleri gibi gelirler de dikkate alınarak hesaplamaların yapılması ve gelir tablolarında gösterilmesi gerekmektedir. 
H. Uyar Oğuz - S. A. Solmaz - B. Ergün 12/2 (2020) 1489-1504

Otel İşletmelerinde gelirlerin muhasebeleştirilmesi;

1) Oda Gelirlerinin muhasebeleştirilmesi,

a. Oda gelirlerinin muhasebeleştirilmesi,

b. Acente aracıllı̆̆ıyla yapılan satışların muhasebeleştirilmesi,

2) Yiyecek-İ̧ecek Satışlarının Muhasebeleştirilmesi,

3) Diğer gelirlerin muhasebeleştirilmesi şeklinde gerçekleştirilir.

Otel İşletmelerinin gelir kalemleri her ne kadar sayfiye oteli ile şehir otelleri arasında farklılık gösterse de genel anlamda aşağıdaki gibi gösterilebilir.

\section{OTEL İŞLETMESİ GELİR KALEMLERI}

\begin{tabular}{|c|c|}
\hline Oda Gelirleri & TOPLAM ZIYAFET GELİRI \\
\hline Kontratlı Oda Gelirleri & Transfer Gelirleri \\
\hline Grup Oda Gelirleri & Araba Transferi \\
\hline Kişisel Oda Gelirleri & Araba Kiralama \\
\hline Geç Check-Out (Çıkış) Gelirleri & Gidiş-Geliş Transfer Hizmet Gelirleri \\
\hline No-Show (Odada konaklama yapmayan konuk ) Gelirleri & TOPLAM ULAŞTIRMA GELİRİ \\
\hline TOPLAM ODA GELİII & Kuru Temizleme Hizmetleri \\
\hline Yiyecek ve İçecek Gelirleri & Çamaşır \\
\hline A RestoranıYiyecek Gelirleri & Toplam Kuru Temizleme Hizmetleri \\
\hline A Restoranı Alkolsüz İçecek Gelirleri & Eğlence Hizmetleri-SPA \\
\hline A Restoranı Alkollü İçecek Gelirleri & Masaj \\
\hline Lobi Bar Yiyecek Gelirleri & TOPLAM EĞLENCE HİZMETLERİ GELİRİ \\
\hline Lobi Bar Alkolsüz İçecek Gelirleri & Ekstra Eğlence Hizmetleri \\
\hline Lobi Bar Alkollü İçecek Gelirleri & Balon Uçuş \\
\hline Minibar Yiyecek Gelirleri & Özel Turlar \\
\hline Minibar İçecek Gelirleri & TOPLAM EKSTRA EĞLENCE HİZMETLERI GELİṘ \\
\hline Oda Servisi Yiyecek Gelirleri & Çeşitli Gelirler \\
\hline Oda Servisi Alkolsüz İçecek Gelirleri & Oda Anahtar Kartı Geliri \\
\hline Oda Servisi Alkollü İçecek Gelirleri & Çiçek Ücreti \\
\hline Diğer Yiyecek Gelirleri & Tip \\
\hline Diğer İçecek Gelirleri & Komisyonlar Genel \\
\hline TOPLAM YİYECEK İÇECEK GELİRI & TOPLAM ÇEŞITTLİ GELİRLER \\
\hline \multicolumn{2}{|l|}{ İletişim Gelirleri } \\
\hline \multicolumn{2}{|l|}{ Uluslararası Telefon Geliri } \\
\hline \multicolumn{2}{|l|}{ Şehir içi/Dışı Telefon Geliri } \\
\hline \multicolumn{2}{|l|}{ Kargo Geliri } \\
\hline \multicolumn{2}{|l|}{ TOPLAM İLETIŞSIM GELİRI } \\
\hline \multicolumn{2}{|l|}{ Ziyafet Gelirleri (Banket Gelirleri) } \\
\hline \multicolumn{2}{|l|}{ Ziyafet Yemeği Gelirleri } \\
\hline \multicolumn{2}{|l|}{ Ziyafet Alkolsüz İçecek Gelirleri } \\
\hline \multicolumn{2}{|l|}{ Ziyafet Alkollü İçecek Gelirleri } \\
\hline \multicolumn{2}{|l|}{ Banket Salonu Kiralama Geliri } \\
\hline Müzik\&Eğlence Gelirleri & \\
\hline
\end{tabular}

Kaynak: Beş Yıldızlı Bir Otel İşletmesinin Gelir Raporu dikkate alınarak hazırlanmıştır. 


\subsubsection{Oda Gelirlerinin Muhasebeleştirilmesi}

Otel işletmelerinde ana faaliyet konusu olan odaların satışlarından elde edilen gelirler 600 YURT İÇİ SATIŞLAR ve 601 YURT DIŞI SATIŞLAR HESABI'nda takip edilmekte; yurt içi satışlar için 391 HESAPLANAN KDV \%8 oranında hesaplanmakta, yurt dışı oda satışlarında ise 3065 sayılı Vergi Usul Kanunu'n göre Yurtdışı Konaklama Bedellerinde belge düzeni İle KDV uygulaması hükmü getirilmiştir. Bununla birlikte ödemelerin tahsilatının genellikle kredi kartı üzerinden gerçekleştirildiği, bunun yanında peşin, banka havalesi gibi yöntemlerin de oda satışlarında uygulandığı görülmektedir.

Oda gelirlerinin muhasebeleştirilmesinde dikkat edilmesi gereken en önemli konu hizmetin ifasının gerçekleşmiş olmasıdır. Yani konuğun mal ve hizmetten yararlanmış olması gerekmektedir. Bununla birlikte bir otel işletmesi 600 YURT İÇi SATIŞLAR HESABI altında faaliyette bulunduğu konularda alt hesaplar açarak takibini gerçekleştirmektedir.

Bilindiği üzere otel işletmelerinde gelirler lokasyona göre farklılık göstermektedir. Örneğin şehir otellerinde banket organizasyonlarından elde edilen gelirler oda gelirlerini geçebilmektedir. Bununla birlikte oda gelirlerinin aşağıdaki gelir kalemlerini de içerdiğini belirtmek gerekir:

- Erken rezervasyon gelirleri,

- Walk-in gelirleri,

- Erken giriş ücretleri,

- Late check-out gelirleri,

- No Show gelirleri,

- Erken rezervasyon gelirleri.

\subsubsection{TFRS 15 Müşterilerle Yapılan Sözleşmelerden Doğan Hasılat Standardına Göre Oda Gelirleri Hasılatının Muhasebeleștirilmesi}

Çalışmanın bundan sonraki kısmında hasılatın otel işletmeleri tarafından muhasebeleştirilmesi kaydı hem TFRS 15'e uygun olarak hem de TFRS 15 dikkate alınmadan yapılacak örneklerle açıklanacaktır.

ÖRNEK OLAY 1: ABC otel işletmesi Ahmet Deniz adlı konuğu için her şey dâhil 5 gece 6 gün konaklama rezervasyonu garantili olarak gerçekleştirmiştir ve buna bağlı olarak sözleşme yapılmıştır. Ahmet Deniz 24 Nisan 2019 tarihinde ödemesinin \%40'ını, otel işletmesine kredi kartı ile geri kalan meblağı ise nakit ödemiştir.

1.Adım: Müşteri ile yapılan sözleşme belirlenir. ABC Otel İşletmesi Konuk ile 5 gece 6 gün her şey dâhil konaklama hizmet sözleşmesi yapmıştır.

2.Adım: Sözleşmedeki ayrı edim yükümlülükleri tanımlanır. Konuk, otel işletmesinden her şey dâhil olarak aşağıdaki mal ve hizmetleri satın alacaktır:

- Oda-Konaklama Hizmeti,

- Yiyecek-İçecek (Otelin her bir outletinden satın alınabilecek yiyecek ve içecekler)

- Spa-Havuz-Deniz Hizmetleri,

- Eğlence Hizmetleri,

- İnternet Hizmetleri

Görüldüğü üzere $\mathrm{ABC}$ otel işletmesinin 5 edim yükümlülüğü bulunmaktadır.

3.Adım: İşlem fiyatı belirlenir: İşletmenin konuğu ile yaptığı sözleşme uyarınca işlem fiyatı günlük $500 \mathrm{TL}$ olarak belirlenmiştir. Toplamda geceleme 2500 TL'dır.

4.Adım: İşlem fiyatı ayrı edim yükümlülüklerine dağıtılır. Otel işletmelerinde üretim ve tüketimin eş zamanlı olarak gerçekleşmesi işlem fiyatı ayrı edim yükümlülüklerinin dağıtımını mümkün kılmaktadır. 
H. Uyar Oğuz - S. A. Solmaz - B. Ergün 12/2 (2020) 1489-1504

5.Adım: Her bir edim yükümlüğü yerine getirildiğinde hasılat muhasebeleştirilir. Otelcilik sektöründe satın alınan mal ve hizmetler zamana yayılı edim yükümlülüklerini içerdiğinden hasılat zamana yayılı olarak ön büro departmanında konuğun foliosunda (hesap kartında) takip edilir. Hizmet sonlandığında ise gerekli hesaplar muhasebeleştirilerek finansal tablolara alınır.

Yukarıdaki örnek olayın muhasebe kayıtları ise aşağıdaki şekilde gerçekleşir:

A) Otel işletmesine kaparonun ödenmesi kaydı:

\begin{tabular}{|c|c|c|}
\hline \multicolumn{1}{|c|}{$\mathbf{2 4 . 0 4 . 2 0 1 9}$} & Borç & Alacak \\
\hline 123. Diğer Hazır Değerler Hesabı & $1000 \mathrm{TL}$ & $1000 \mathrm{TL}$ \\
349. Alınan Sipariş Avansları Hesabı & & \\
\hline
\end{tabular}

B) TFRS 15 gereğince konuğun otel işletmesine giriş yaptığı andan itibaren yapılan kayıt:

\begin{tabular}{|c|r|r|}
\hline \multicolumn{1}{|c|}{ 05.07.2019 } & \multicolumn{1}{|c|}{ Borç } & Alacak \\
\hline \begin{tabular}{c|c} 
181. Gelir Tahakkukları Hesabı \\
349. Alınan Diğer Avanslar Hesabı
\end{tabular} & $300 \mathrm{TL}$ \\
600. Yurt İçi Satışlar Hesabı & $200 \mathrm{TL}$ & \\
391. Hesaplanan KDV Hesabı & & $460 \mathrm{TL}$ \\
& & $40 \mathrm{TL}$ \\
\hline
\end{tabular}

TFRS 15 gereğince başlangıçta alınan avans ile konaklama yapılan her bir gün için gelirin dağıtımı yukarıdaki yevmiye kaydı şeklinde olmalıdır.

A) TFRS 15'e göre konuğun otelden ayrilması:

\begin{tabular}{|l|l|r|}
\hline \multicolumn{1}{|c|}{$\mathbf{1 1 . 0 7 . 2 0 1 9}$} & \multicolumn{1}{|c|}{ Borç } & Alacak \\
\hline 100.Kasa Hesabı & $1500 \mathrm{TL}$ & \\
102. Bankalar Hesabı & $1000 \mathrm{TL}$ & \\
\multicolumn{1}{|c|}{ 181. Gelir Tahakkukları Hesabı } & & $1500 \mathrm{TL}$ \\
123.Kredi Kartından Alacaklar Hsb. & & $1000 \mathrm{TL}$ \\
\hline
\end{tabular}

TFRS 15' e göre konuğun otelden ayrılması ile birlikte edim yükümlülüğü yerine getirilmiştir. Artık elde edilen gelir yevmiye kayıtları vasıtasıyla finansal tablolara aktarılabilir.

\subsubsection{TFRS 15 Müşterilerle Yapılan Sözleşmelerden Doğan Hasılat Standardı Dikkate Alınmadan Oda Gelirleri Hasılatının Muhasebeleștirilmesi}

TFRS 15 dikkate alınmayarak yapılacak oda gelirleri (uygun olmayan kayıt) muhasebe kaydı ise şu şekilde gerçekleşecektir:

1.Kayıt:

\begin{tabular}{|c|c|c|}
\hline \multicolumn{1}{|c|}{$\mathbf{2 4 . 0 4 . 2 0 1 9}$} & Borç & Alacak \\
\hline 102. Bankalar Hesabı & $1000 \mathrm{TL}$ & \\
349 Alınan Diğer Avanslar Hesabı & & $1000 \mathrm{TL}$ \\
\hline
\end{tabular}


H. Uyar Oğuz - S. A. Solmaz - B. Ergün 12/2 (2020) 1489-1504

\begin{tabular}{|c|c|c|}
\hline \multicolumn{1}{|c|}{$\mathbf{0 5 . 0 7 . 2 0 1 9}$} & Borç & Alacak \\
\hline 181.Gelir Tahakkukları Hesabı & $2500 \mathrm{TL}$ & \\
600.Yurt İçi Satışlar Hesabı & & $2300 \mathrm{TL}$ \\
391.Hesaplanan KDV Hesabı & & $200 \mathrm{TL}$ \\
\hline
\end{tabular}

\section{Kaylt:}

\begin{tabular}{|l|l|r|}
\hline \multicolumn{1}{|c|}{$\mathbf{1 1 . 0 7 . 2 0 1 9}$} & \multicolumn{1}{|c|}{ Borç } & Alacak \\
\hline 100.Kasa Hesabı & $1500 \mathrm{TL}$ & \\
349. Alınan Diğer Avanslar Hesabı & $1000 \mathrm{TL}$ & 2500 TL \\
\multicolumn{1}{|c|}{ 181.GelirTahakkukları Hesabı } & & \\
\end{tabular}

\section{Kayit:}

TFRS 15'e uygun yapılan muhasebe kayıtları ile TFRS15 dikkate alınmayarak gerçekleştirilen muhasebe kayıtları incelendiğinde; TFRS 15'e uygun kayıtta edimin gerçekleşip gerçekleşmeme durumu dikkate alınarak ilgili muhasebe kayıtlarının yapıldığı, diğerinde ise bu durumun dikkate alınmadığı görülmektedir. Konuğun konaklamasını gerçekleştirmeden önce elde edilen gelirin muhasebe kayıtlarında yapılacak böylesi bir kayıt gerçekten uzak olacaktır. Bu durum ise başta üst yönetim olmak üzere işletme sahipleri ve/veya uluslararası otel işletmeleri için yanıltıcı sonuçların ortaya çıkmasına sebep olabilecektir.

Bu nedenle TFRS 15'e uygun hasılat kayıtlarının yapılması gerçekçi veriler elde edilmesi için önemlidir. Bundan sonraki örneklerde makale sayfa kısıtından dolayı yalnızca TFRS 15'e uygun kayıtlara yer verilecektir.

\section{ÖRNEK OLAY 2:}

DEF Seyahat acentası 40 kişilik bir grup için 4 gecelik, oda+kahvaltı rezervasyon yaptırmıştır. Otel işletmesinin acentaya verdiği oda fiyatları (KDV dâhil) şöyledir;

- Tek kişilik oda: $150 \mathrm{TL}$,

- İki kişilik oda, kişi başı: $120 \mathrm{TL}$,

- Üç kişilik oda $100 \mathrm{TL}$

Acente ödemenin \%50'sini konfirmasyon sonrası otel işletmesine havale etmiş, konaklama gerçekleştikten bir hafta sonra da acenta geri kalan meblağı otele yine havale olarak göndermiştir.

Yukarıdaki örnek olayın muhasebe kayıtları ise aşağıdaki şekilde gerçekleşir:

Konukların otele bir günlük maliyeti: Tek kişilik oda: $150 \times 5=750 \mathrm{TL}$

$$
\begin{aligned}
& \text { İki kişilik oda: } 120 \times 2=240 \mathrm{TL} \\
& \text { Üç kişilik oda: } 100 \times 3=300 \mathrm{TL}
\end{aligned}
$$

$$
1290 \times 4 \text { gün }=5160 \mathrm{TL}
$$

A) TFRS 15' e göre otel işletmesine yapılan havalenin muhasebe kaydı aşağıdaki gibidir.

\begin{tabular}{|c|c|c|}
\hline \multicolumn{1}{|c|}{$\mathbf{2 4 . 0 4 . 2 0 1 9}$} & Borç & Alacak \\
\hline 102. Bankalar Hesabı & $2580 \mathrm{TL}$ & 2580TL \\
349 Alınan Diğer Avanslar Hesabı & & \\
\hline
\end{tabular}

B) TFRS 15' e göre konuklar otele giriş yaptıkları günden itibaren her bir gün için gerçekleştirilecek kayıt ise aşağıdaki şekilde olmalıdır: 
H. Uyar Oğuz - S. A. Solmaz - B. Ergün 12/2 (2020) 1489-1504

\begin{tabular}{|l|l|r|}
\hline \multicolumn{1}{|c|}{$\mathbf{0 5 . 0 7 . 2 0 1 9}$} & \multicolumn{1}{|c|}{ Borç } & Alacak \\
\hline 181.Gelir Tahakkukları Hesabı & $645 \mathrm{TL}$ & \\
349.Alınan Diğer Avanslar Hesabı & $645 \mathrm{TL}$ & $1186,2 \mathrm{TL}$ \\
600. Yurt İçi Satışlar Hesabı & & $103,2 \mathrm{TL}$ \\
391. Hesaplanan KDV Hsb. & & \\
\hline
\end{tabular}

C) Konaklama gerçekleştikten bir hafta sonra alınan havale kaydı;

\begin{tabular}{|c|c|c|}
\hline \multicolumn{1}{|c|}{$\mathbf{1 5 . 0 7 . 2 0 1 9}$} & Borç & Alacak \\
\hline & & \\
\hline 102. Bankalar Hesab1 & $2580 \mathrm{TL}$ & \\
181. Gelir Tahakkukları Hesab1 & & $2580 \mathrm{TL}$ \\
\hline
\end{tabular}

\subsubsection{Yiyecek-İçecek Gelirlerinin Muhasebeleştirilmesi}

Otel işletmelerinde yiyecek-içecek kalemleri işletmenin oda satışı türüne göre farklılık göstermektedir. Örneğin her şey dâhil konaklama ile çalışan otellerde yiyecek-içecek gelirleri oda fiyatı içerisinde değerlendirilir ve oda ücretinden bir pay (breakdown) ayrılır. Bu oran otel tarafından belirlenmektedir. Genellikle bu oran \% 7 kahvaltı, \% 15 öğle yemeği ve \% 23'de akşam yemeği şeklinde olmaktadır. Bazı durumlarda fiyatı ne olursa olsun direkt kahvaltı, öğle yemeği ve akşam yemeği olarak sabit tutar belirlenebilir. Oda+kahvaltı otellerinde de bu uygulama vardır. Örneğin A oteli her oda için 17 avro kahvaltı masrafı ayırabilir. Bu işlem yiyecek içecek maliyetlerini kontrol altında tutmak ve kolay hesap yapmak için uygulanmaktadır. Son kanunla birlikte otellerde konaklama hariç alkollü içecek bedeli için satışı yapılan her bir ürüne \% $18 \mathrm{KDV}$ uygulanmaktadır. Bu oran yemek-çay ve pasta vb. için ise \% 8 şeklindedir. Bununla birlikte otel işletmelerinde bulunan restoranlar ve barlarda (outletler) yapılan satışlar ile banket organizasyonlarından elde edilen yiyecek-içecek gelirlerinin de muhasebeleştirilmesi gerekir. Yalnız banket organizasyonlarında, organizasyon gerçekleşmeden elde edilen gelir kayıt (charge) edilememektedir. TFRS 15 "edim yükümlülüğü yerine getirildikten sonra muhasebe kaydı yapılı" gereğince de ilgili kayıtların yapılması gerekmektedir. Aynı zamanda eğer yapılan anlaşma garantili bir anlaşma ise otel işletmesi iptal durumunda dahi ücretini alacak ve gelir olarak ilgili tarihler için muhasebe kayıtlarını gerçekleştirecektir.

Konu iki farklı örnek olay kapsamında değerlendirilirse;

ÖRNEK OLAY 3: ABC Otel işletmesinin bir günlük yiyecek-içecek gelirleri tablosu aşağıdaki gibidir. Otel işletmesinin farklı outletlerinden elde edilen gelirin \%83 kredi kartı ile geri kalanı ise nakit alınmıştır.

\begin{tabular}{|l|c|c|c|}
\hline \multicolumn{3}{|c|}{ OTEL İŞLETMESİ GÜNLÜK YİYECEK-İÇECEK GELİR KALEMLERI } \\
\hline & \multicolumn{3}{|c|}{ GÜNLÜK } \\
\hline & & Kdv & Brüt \\
\hline Yiyecek ve İçecek Gelirleri & & \\
\hline Restoran Alkollü İçecek & $1.158,39 \mathrm{TL}$ & $208,51 \mathrm{TL}$ & $1.366,90 \mathrm{TL}$ \\
\hline Yemeği & $1.257,63 \mathrm{TL}$ & $226,37 \mathrm{TL}$ & $1.484,00 \mathrm{TL}$ \\
\hline Salon Alkollü İçecek & $1.525,42 \mathrm{TL}$ & $274,58 \mathrm{TL}$ & $1.800,00 \mathrm{TL}$ \\
\hline Salon Alkolsüz İçecek & $188,99 \mathrm{TL}$ & $34,02 \mathrm{TL}$ & $223,01 \mathrm{TL}$ \\
\hline Toplam Yiyecek \& İçecek Gelirleri & $\mathbf{4 . 1 3 0 , 4 3} \mathrm{TL}$ & $\mathbf{7 4 3 , 4 8} \mathrm{TL}$ & $\mathbf{4 . 8 7 3 , 9 1} \mathrm{TL}$ \\
\hline
\end{tabular}


Buna göre TFRS 15'uygun muhasebe kaydı;

\begin{tabular}{|c|l|r|}
\hline \multicolumn{1}{|c|}{$\mathbf{1 1 . 0 7 . 2 0 1 9}$} & \multicolumn{1}{|c|}{ Borç } & Alacak \\
\hline 100 Kasa Hesabı & $702,17 \mathrm{TL}$ & \\
123 Kredi Kartından Alacaklar Hesabı & $3428,26 \mathrm{TL}$ & \\
600 Yurt İçi Satışlar Hesabı & & $4130,43 \mathrm{TL}$ \\
391 Hesaplanan KDV Hesabı & & $743,48 \mathrm{TL}$ \\
\hline
\end{tabular}

Yukarıdaki muhasebe kaydında görüldüğü üzere $\mathrm{ABC}$ otel işletmesinin bir günlük brüt yiyecek içecek geliri toplamı 4873,91 TL olarak hesaplanmıştır. Bu gelirin \%83'ü kayıtlara 123 Kredi Kartından Alacaklar Hesabında borç ve geri kalanı 123 Kredi Kartından Alacaklar Hesabında yine borç olarak kaydedilmelidir.

\section{SONUÇ ve ÖNERILER}

Önceki çalışmalardan elde edilen bulgular incelendiğinde birçoğunda UFRS ‘ye zorunlu geçişin hisse senedi getirilerini arttırdığı, öz sermaye maliyetlerini azalttığı ve piyasa likiditesini arttırdığı görülmüştür (Armstrong vd., 2010; Christensen vd., 2007; Daske vd., 2008; Li, 2010). Bu bağlamda Avrupa Birliği üyesi ülkeler UFRS ‘ye zorunlu geçişi 2005 yılından itibaren sağlamışlardır. Türkiye'de ise 14 Şubat 2011 tarihinde yasalaşan Yeni Türk Ticaret Kanunu ile birlikte uluslararası standartlarda ticaret ortamına geçilmiştir (Deloitte, 2011: 5).

Bu çalışmada işletmelerin devamlılığı ile öngörülebilir bir gelecekte de (en az bilanço tarihinden itibaren 12 aylık dönem) faaliyetlerini sürdüreceği varsayımına dayanarak ekonomik kararlar için bilgi sağlamak amaçlı hazırlanacak olan finansal tablolar Müşteri Sözleşmelerinden Hasılat yönüyle ele alınmıştır (UFRS, 2006: 68).

TFRS 15 Müşteri Sözleşmelerinden Hasılat Standardı daha önce hiç incelenmemiş olan ve hizmet sektöründe faaliyet gösteren otel işletmeleri açısından değerlendirilmiştir. Yeni standart, beş aşamalı edim yaklaşımı ile otel işletmelerinde gelirin edim yükümlülüklerinin tanımlanması, edim yükümlülüklerinin yerine getirilmesi, işlem bedelinin belirlenmesi ile işlem bedelinin edim yükümlülüklerine dağıtım aşamalarını içermektedir.

Otel işletmelerinde gelirler oda gelirleri, yiyecek-içecek gelirleri ve diğer gelirler olmak üzere 3 grupta toplanmaktadır. Bu gelirler deniz kenarındaki tesisler (sayfiye otelleri) ile şehir otelleri arasında farklılık gösterebilir. Öyle ki bazı şehir otellerinde banket (ziyafet) organizasyonlarından elde edilen gelirler oda gelirlerini aşabilmektedir. Her ne kadar bu gelir kalemleri tesisin bulunduğu yere göre farklılık gösterse de muhasebe kayıtlarının 600 Yurt İçi Satışlar Hesabı, 181 Gelir Tahakkukları Hesabı ekseninde gerçekleştiği görülmektedir.

Otel işletmelerinde restoran ve barlardan elde edilen tüm günlük gelirler tek mahsupta ancak ayrı ayrı hesaplara atılarak muhasebeleştirilir. Bunun en önemli sebebi tesislerin hangi kalemlerden en fazla gelir elde ettiklerinin analizlerini sağlıklı yapabilmelerini sağlayabilmektir. Böylelikle üst yönetime daha açı bilgilendirme yapılabilecektir.

Otel işletmeleri muhasebe kayıtlarını aşağıdaki gibi hazırlayacaktır:

600 XX Konaklama Geliri 5.000 (alacak)

600 XX X Restaurant Geliri 4.000 a

600. XX X Bar Geliri $\quad 1.000$ a

600. XX Spa Geliri $\quad 1.000$ a

600 XX Diğer Gelir $\quad 1.000$ a

$391 \% 18 \mathrm{KDV}$ 
$391 \% 8 \mathrm{KDV}$

181 Gelir Tahakkukları hesabı

Banket (ziyafet) satışlarından elde edilen gelir ise;

600 XX Banket Yiyecek Geliri

600 XX Banket İçecek Geliri

600 XX Banket Alan geliri

600 XX Banket Müzik bedeli

600 XX Banket Ses Işık Bedeli

600 XX Banket Diğer Gelir

$391 \mathrm{KDV} \% 18$

181 Gelir Tahakkukları hesaplarında izlenir.

TFRS 15 Müşteri Sözleşmelerinden Hasılat standardına göre edim yükümlülükleri mal ve hizmetlerin, satın alımı yapılmadan muhasebe kayıtlarına yansıtılmadığı görülmektedir. Öyle ki konuk, grup ya da acente önceden yaptırdığı rezervasyon için sözleşme karşılığı belirli bir miktar ödeme yapabilir. Bu ödemeler havuz hesap adı verilen ön büroda 181 Gelir Tahakkukları Hesabına atılır. Konuk otelden hizmet aldıkça bu hesap ödemenin alınış şekline göre ilgili hesaba aktarılır ve satış 600 Yurt İçi Satışlar Hesabında izlenir. TFRS 15 Müşterilerle Yapılan Sözleşmelerden Doğan Hasılat standardına göre oda gelirlerinin muhasebeleştirilmesinde:

- Müşteri (konuk) ile hizmet sözleşmesinin imzalanmış olması,

• Hizmet sözleşmesinde edim yükümlülüklerinin açıkça tanımlı olması,

- İşlem fiyatının belirlenmiş olması,

- Her bir edim yükümlülüğü yerine getirildiğinde hasılatın muhasebeleştirilmiş olması hususlarına dikkat edilmesi gerekmektedir.

Ayrıca müşteri (konuklar) otelden ayrılmadan edim yükümlülükleri yerine getirilmiş sayılmaz. Konuğun otelden ayrılması ile birlikte elde edilen gelirin yevmiye kayıtları vasıtasıyla finansal raporlara aktarımı yapilmalıdır.

Bu çalışma TFRS Müşteri Sözleşmelerinden Doğan Hasılat Standardının Otel işletmelerinde uygulaması ile ilgili yapılan ilk çalışma olma niteliği taşımaktadır. Araştırmacılar bundan sonraki çalışmalarında uluslararası otel işletmeleri açısından TFRS Müşteri Sözleşmelerinden Hasılat kavramını inceleyerek yazına kazandırabilir ayrıca döviz cinsinden KDV hesaplamalarının yer aldığı çalışmalar hazırlayarak da literatüre katkıda bulunabilirler.

\section{KAYNAKÇA}

Ağca, A. ve Aktaş, R. (2007). Uluslararası Muhasebe/Finansal Raporlama (IAS/IFRS) Standartları İMKB'de Yer Alan Firmaların Finansal Tablolarını Nasıl Etkiledi, Dumlupınar Üniversitesi Sosyal Bilimler Dergisi, Sayı 18, Ağustos, ss. 227- 242.

Armstrong C. S., Barth M.E., Jagolinzer A.D., et al. (2010). Market reaction to the adoption of IFRS in Europe. The Accounting Review 85: 31-61.

Ataman, B.Cavlak,H.,(2017). TFRS 15 Müşteri Sözleşmelerinden Hasılat: Temel İlkelerin İncelenmesi ve Bir Uygulama, Marmara Üniversitesi, İktisadi ve İdari Bilimler Fakültesi, Cilt 39, Sayı 2

Bostancı, S. (2002). Küreselleşen Muhasebede Standartlaşma ve Türkiye Muhasebe Standartları Kurulu. Mali Çözüm Dergisi.

Cemalciler, Ö. ve Önce, S. (1999), Muhasebenin Kurumsal Yapısı, Eskişehir: Anadolu Üniversitesi Kütüphane ve Dokümantasyon Merkezi 
Christensen H. B., Lee E. and Walker, M. (2007). Cross-Sectional Variation İn The Economic Consequences Of International Accounting Harmonization: The Case Of Mandatory IFRS Adoption In The UK. The International Journal of Accounting (42): 341-379.

Daske H, Hail L, Leuz C, et al. (2008) Mandatory IFRS Reporting Around The World: Early Evidence On The Economic Consequences. Journal Of Accounting Research (46): 1085-1142.

Deloitte (2008). IFRS in Tourismi Hospitality and Leisure More than Accounting, https://www.iasplus.com/en/binary/dttpubs/0810ifrstourism.pdf, Erişim Tarihi : 17.01.2019.

DUMAN, F. C.(2007). 18 Nolu Türkiye Muhasebe Standardında Hasılatın Oluşumu, Yayınlanmamış Yüksek Lisans Tezi, Başkent Üniversitesi Sosyal Bilimler Enstitüsü, Ankara.

EY, (2016), A Closer Look at The New Revenue Recognition Standard, www.ey.com

Feng, Z. Y., Wang, Y.C. and Huang, H.W.(2017) Does IFRS Adoption Decrease The Cost Of Equity Of The Global Tourism Firms?,Tourism Economics, Vol 23(8): 1615-1631.

http://www.tdk.gov.tr

İbiş C, Özkan S. (2006). Uluslararası Finansal Raporlama Standartları (UFRS)'na Genel Bakış, Mali Çözüm Dergisi, Sayı: 74.

İbiş, C. ve Akarçay, A. (2003). IOSCO Deklarasyonu ve Menkul Kıymet Borsalarında IAS'ın Uygulanması Süreci", 6. Muhasebe Denetimi Sempozyumu, s.244-255.

KGK (2018). Finansal Raporlamaya İlişkin Kavramsal Çerçeve, TMS/TFRS Seti, pr.4.25.a

KGK, (2018) Türkiye Finansal Raporlama Standardı 15 Müşteri Sözleşmelerinden Hasılat

KGK, (2018) Türkiye Muhasebe Standard1 18 Hasılat.

Kılıç,G.,(2017), UFRS Müşteri Sözleşmelerinden Doğan Hasılat Standardının Değerlendirilmesi, Başkent Üniversitesi, Sosyal Bilimler Enstitüsü, İşletme ABD, Ankara.

Lengerlioğlu, H. (2014). Tedarik Zinciri Yönetiminde Kontratlar, www.academia.edu.com. Erişim Tarihi: 01.10.2015.

Li, S.(2010). Does Mandatory Adoption Of International Financial Reporting Standards In The European Union Reduce The Cost Of Equity Capital? The Accounting Review (85) 607-636.

Marquez,A.C.,Blanchar, C. (2004). The Procurement of Strategic Parts.Analysis of a Portfolio of Contracts with Suppliers Using a System Dynamics Simulation Model, Intelnational Journal of Production Economics, 88,29-49.Yayınevi, Ankara.

Milli Eğitim Bakanlığı, (2013). Önbüroda Seyahat İşlemleri, Ankara.

Olsen, L., Weirich, R., (2010) New Revenue-Recognition Model, The Journal of Corporate Accounting and Finance / November/December 2010.

Saban ,M.,Gürkan, S., ve Vargün, H.,(2019),TFRS 15 Müşteri Sözleşmelerinden Hasılat Standardı: İnşaat Sözleşmeleri Üzerine Bir Uygulama),Muhasebe ve Vergi Uygulamaları Dergisi .

Sağlar, J., ve Yüce, D. (2015). Bağımsız Denetimde Kamu Gözetim Kurumunun Rolü Ve Kurumdan Beklentilerin Tespitine Yönelik Bir Araştırma. Niğde Üniversitesi İktisadi ve İdari Bilimler Fakültesi Dergisi, 8(3), 45-57.

Sağlar, J.ve Ever, D.,(2019), Büyük ve Orta Büyüklükteki İşletmeler İçin Getirilen Finansal Raporlama Standartlarının Etkileri, Osmaniye Korkut Ata Üniversitesi, Journal of Economics and Administrative Sciences, Vol: 3, Issue:2,December,2019),pp.299-310.

Şengel, S.,(2017), Konaklama İşletmeleri Muhasebesi, Detay Yayıncılık, Ankara.

Usul, H. ve Kıymık, H. (2010). Uluslararası Muhasebe Standartlarının Entegrasyon Sorunları, Süleyman Demirel Üniversitesi Sosyal Bilimler Enstitüsü Dergisi, 2010/ 2, Sayı 12, ss. 123-139.

Yurdakul, H. (2015), Satın Alma Yönetimi, Süreçler ve Uygulamalar, Nobel Yayınları, Ankara.

Yücenurşen, M., Peker, A. A., Apak, İ. ve Polat, Y. (2014), TMS 18 Hasılat Standardı Çerçevesinde Hasılatın Muhasebeleştirilmesi ve Özellik Arz Eden Durumlar, Aksaray Üniversitesi İktisadi ve İdari Bilimler Fakültesi Dergisi, Cilt 6, Sayı 2, ss. 1-8 